\title{
Climate Change and Food Insecurity Dynamics in the Rural Limpopo Province of South Africa
}

\author{
Abiodun Olusola Omotayo \\ North West University, Mafikeng Campus, South Africa \\ omotayoabiodun777@gmail.com
}

\begin{abstract}
In the developing nations of the world, poor gross domestic product growth has shown serious vacuum to be filled in order to achieve the sustainable development goals. In that regard, this research article intends to contribute to the sustainable development goals of the United Nation's goal by explaining the rural food insecurity in the light of climate change dynamic in some selected rural communities of Limpopo Province, South Africa. The data employed in the study were collected from 120 randomly selected rural household heads. Data were analysed with descriptive (frequency, mean etc.) and inferential statistics (Principal component Analysis (PCA), Tobit and Probit Regression) which were properly fitted $(\mathrm{P}<0.05)$ for the set research objectives. Descriptive results indicate that the average age of the respondents was 52 years with $60 \%$ of the household heads being married and a mean household size of 5.The study concluded that there is climate change effect and food insecurity in the study area and therefore recommended among others that the government of South Africa should endeavour to implement a more rural focused food securityclimate change policies in order to relieve the intensity of food insecurity situations among these disadvantaged rural dwellers of the province as well as to entrench a policy of long term development of agriculture. Finally, the study emphasized that the rural farming households should be enlightened through proper extension services to carry out climate change adaptation and mitigation measures in alleviating the food insecurity situation in the rural communities of the province.
\end{abstract}

Keywords: Climate change, food insecurity, Tobit regression, Probit regression, Principal Component Analysis

\section{Introduction}

Climate change is quickly becoming one of the most pressing threats to many critical sectors of civilization. It currently remains one of the most recognized spectre that is fiercely argued, contested and debated worldwide. Manyatsi et al. (2010), defined climate change as the long-term significant change in the average weather that a given region experience. The Intergovernmental Panel on Climate Change (IPCC,2007) identified Africa as 'one of the most vulnerable continents to climate variability and change because of multiple stresses and low adaptive capacity'. Sub Saharan Africa have been confirmed as one of the most severely affected regions to climate change since most of the population are dependent on climate sensitive agricultural-economic activities. IFAD (2008), affirms that climate change poses considerable threat to rural farmers and their communities in developing countries, especially those living in the tropics and sub-tropics. Climate change in the light of increasing temperatures, land area suitable for agriculture, length of planting and breeding seasons, yield potentials cum livestock's output, particularly along the arid and semi-arid area are expected to decrease. Climate variability in the sub regions of Africa is associated with increasing the frequency and intensity of climate hazards especially drought (Joosten \& Grey, 2017). In sub-Saharan Africa, where climate change is however expected to be the most acute, translating into intense food insecurity, increased water stress and resultant increased exposure to disease and other health problems. Incidentally, individual suffering from poor health may be weak, unable to work and automatically unable to provide for their farming households' and other dependants (Omotayo et al., 2016;Omotayo, 2017).

To this effect, the Department of Agriculture, Forestry and Fisheries (DAFF, 2012), embarked on an ambitious sector plan which addresses rural development in South Africa, focusing on improving competitiveness, sustainability, equity and transformation. The plans include supporting the fast-tracking of land reform and providing support to smallholder farmers, including facilitating access to markets. Despite the urgent need to adapt to climate change in South Africa at both national and local levels, the rate of adaptation to climate change and its food security ripple effect is still low owing to the limited options for alternative livelihoods, lack of support for climate change adaptation actions, limited knowledge of climate change adaptation options, poor planning and limited knowledge of future climate change scenarios. In this study, Climate change is considered as the distinct change in measures of climate such as temperature, rainfall, snow or wind patterns lasting for decades or longer (US Environmental protection agency, USEPA, 2009). The direct 
impacts of climate variables such as air, temperature, humidity, wind speed and other climate factors influence animal and plant performance such as growth, milk production, wool production and reproduction (Lal, Alavalapati, \& Mercer, 2011). This study is different from other previous studies because it fitted climate change indices such as drought, soil erosion, high temperature, etc. in Principal Component Analysis cum Tobit regression. Specifically, the study sought to explain respondents' socio economic characteristics, explain the perception and knowledge of climate change, assess the determinants of climate change in the study area as well as to analyse the factors influencing the farmers' food security status (Using Probit regression analysis) in the rural Limpopo Province of South Africa thereby, bringing out substantial policy recommendation that will prompt the government of South Africa in timely intervention.

\section{Methodology}

Study Area: The research was conducted in the Sekhukhune district of Limpopo province which is situated in the south-eastern part of Limpopo province. Sekhukhune district municipality is located in the Limpopo Province, the northernmost part of South Africa (Stats SA, 2011). It is bordered by Guateng province to the south, Mpumalange province to the east as well as Waterberg towards the West. Sekhukhune is relatively accessible with the use of its relatively extensive road network system. It is characterized by scattered pattern of human settlement and contains a large number of rural villages with both limited economic infrastructure opportunities and services of a reasonable standard. The district is the smallest in the province, making up $11 \%$ of its geographical area. It is comprised of five local municipalities: Fetakgomo, Makhuduthamaga, Elias Motsoaledi, Ephraim Mogale and Greater Tuberatse. The district covers $14528 \mathrm{~km}^{2}$ and population of 1076840 with $5 \%$ of the districts population estimated to live in urban area. The major occupations of the people include mining, trade, financial and business services and agriculture. The choice of the province was based on the popular small scale agricultural activities as well as the fact that it is the second poorest province and food insecure in the nation (Perret et al., 2005).

Method of Data Collection: Primary data were used in this study. These data were collected in year 2016 by administering a structured questionnaire to respondents in the study area. The data collected include demographics characteristics, housing conditions, climate changeperception and adaptation, and foodconsumption expenditures. The questions were translated into the local language of the respondents during administration and their response was recorded in English language.

Population, Sampling Procedure, and Sample Size: A multi-stage sampling procedure was adopted in the selection of 120 respondents in the study. Questionnaires were administered in the two local municipalities purposively selected from the earlier stated five municipalities based on the population, as well as the prominence of agricultural activities in these rural communities. The second stage was the selection of 10 villages: Ga-masha, Ga-Mampuru, Ga-Phaspha, Ga-Mouru, Santeng, Mokotaseng, Mapodile, Ga-Manoke, Kgautswane and Pumahe were administered to respondent from each of the communities while the last and final stage of sampling was the selection of 12 farming household heads from each of the communities. The samples were representatives, sufficiently robust and satisfactory to give estimates at local government, state and at the regional level.

Statistical Analysis: Descriptive statistics such as frequency, percentages, mean, food security index and Principal Component Analysis, Tobit and Probit regression were employed to fulfil the objectives of the study. Principal Component analysis was used to form a climate change index which was later used as dependent variable in the Tobit regression analysis. In order to determine the food security status of the rural households, the households were classified into food secure and food insecure households, using the food security index. The food security index formula is given by:

$\mathrm{Fi}=$ Per capita food expenditure for the ith household

$2 / 3$ mean per capita food expenditure of all households

Where Fi = Food security index; When Fi $\geq 1=$ Food secure ith household and Fi $\leq 1=$ Food insecure ith household. 
In that regard, a food secure household is therefore the household whose per capita monthly food expenditure fall above or is equal to two third of the mean per capita food expenditure. On the other hand, a food insecure household is that whose per capita food expenditure falls below two-third of the mean monthly per capita food expenditure (Omonona et al., 2007 as cited by Ifeoma and Agwu, 2014). Additionally, the number of food secure/insecure households in the state was determined by taking the frequency of the food secure/insecure households. The headcount ratio $(\mathrm{H})$ of food security was calculated to measure the percentage of the population of households that are food secure/insecure. The headcount index formula is given by; Headcount index $(\mathrm{H})=\mathrm{M} / \mathrm{N}$ Where $\mathrm{M}=$ number of food secure/insecure households $\mathrm{N}=$ the number of households in the sample.

Modelling the Correlates of Climate Change Indices in some Selected Rural Communities of Limpopo Province: Estimating the determinants of climate change poses both econometric and climate modelling challenges. The econometric challenge of estimating the effect of some socio economic and environmental factors on dependent variables of interest has been well appreciated, as has the climate change modelling challenge of simulating changes in the distribution. The variables selected for constructing climate change index were (erratic rainfall, perception of drought, high temperature, presence of soil erosion, perception of wind storm) highlighted in the questionnaire and described in Table 2. The variables selected for constructing the food index were coded as 1 if yes and 0 otherwise, in order to provide a simple measure of the aggregation of these climate change indicators. The index was computed as follows:

$$
\text { Climatechangeindex }=D_{\mathrm{i}}+\beta_{\mathrm{i}} \sum_{n=1}^{C} X_{\mathrm{ir}}+z^{0}
$$

Where climate change index is the Composite index, $D_{\mathrm{i}}$ and $\beta_{\mathrm{i}}$ represents the parameters to be estimated. However, $X_{\text {ir }}$ represents the vector of independent variables coded aserratic rainfall (yes $=1,0$ otherwise), perception of drought (yes $=1,0$ otherwise), high temperature (yes $=1,0$ otherwise), presence of soil erosion (yes $=1,0$ otherwise), perception of wind storm (yes $=1,0$ otherwise), and $z_{0}$ represents the error term. Using the index generated by PCA as the dependent variable, the Tobit regression analysis was used to analyse the determinants of climate change in the study area. The standard Tobit model can be written as (Tobin, 1958):

$y^{*}=x^{\prime} \beta+$ uiui $\sim N\left(0, \sigma^{2}\right) i=1, \ldots, n$.

$\mathrm{yi}=\mathrm{yi}^{*}$ if $\mathrm{yi}^{*}>0$; $\mathrm{yi}=0$ otherwise; $\mathrm{yi}=$ climate change index (earlier generated)

The explanatory variables are: Household Size, type of crop grown, household heads' age, educational status of the head, credit accessibility, food security status, reduction in soil moisture, asset ownership, knowledge of climate change, household income, food expenditure, climate change adaptation, agricultural activities, release of methane or Co from farm, bush burning practice, tree cutting, farm activities leading to soil erosion. Where: $x i$ is a vector of explanatory variables corresponding to the ith respondent, yi, are observed proportion of the ith respondents with climate change $\mathrm{yi}^{*}$ is an unobserved continuous latent variable assumed to determine the value of yi while; ui is the disturbance term.

Probit Model of Factors Influencing the Farmers' Food Security Status in the Limpopo Province: Probit model was used to identify the factors influencing the achievement of food security among the respondent households. Probit model could be represented as:

$\mathrm{Y}=\sum \alpha \mathrm{X}+\mathrm{ei}$

Where $Y=$ vector of dependent variable (1 for food secure households; 0 for food insecure households) as previously explained; $\mathrm{X}=$ vector of explanatory variables (predictors); $\alpha=$ Probit coefficients; $\mathrm{e}$ = random error term. The explanatory variables included in the model are: Household size, gender of the household head, employment status, age of the household's head, experience of shock, theft incidence, climate change, high food price, educational status, possession of asset, house materials, farm size, farming experience, food expenses.

\section{Results}

Socio-Economic Characteristic of the Rural Communities in Limpopo Province of South Africa: The result shown in Table 1 revealed the fact that a considerable number i.e. $56.67 \%$ of the respondents were male. This shows that there are more male headed households in the study area than female headed (43.33\%) counterparts. The average age of the household head in the study area was 52 years old with a 
standard deviation of 13.6 while the general population is considerably younger with ageing household heads. This corroborates with the finding of De Cock et al. (2013). In addition, there were no significant differences between the household sizes of the different communities in the study as majority of the respondents' i.e. 80.83\% have 5 households size thereby giving an average household size of 5 members in the study. Marital status of the respondents is principally partnership in nature with $30 \%$ of them living as patners.15.83\% were married while about 27.50 were divorced. In addition, household heads have a generally low level of education. Furthermore, some $30.83 \%$ have had no schooling, although most of the household heads have either completed primary $33.33 \%$ have had some secondary education $32.50 \%$ while the lowest percentage i.e. 3.33\%. The low levels of education are skewed towards the older generation, as they grew up in the apartheid era and had limited access to formal education Adeniyi et al. (2016). An average annual income of R18000 (\$1325.55) was recorded in the study which was supported by the respondents' response on their possession of asset which $40 \%$ of them claimed not to have. This indicate a high level of poverty in the study area while $59.17 \%$ of the respondent were found to be food insecure. This is in line with the report on a survey in Sekhukhune by Rule et al. (2005) which confirmed that most of the households experienced lack of food or money during January and February.

Table 1: Socio-economic characteristic of the rural Household heads(n=120)

\begin{tabular}{|c|c|c|c|c|}
\hline Socio-economic Variable & Frequency & Percentage & Average & $\begin{array}{l}\text { Standard } \\
\text { Deviation }\end{array}$ \\
\hline \multicolumn{5}{|l|}{ Gender } \\
\hline Male & 68 & 56.67 & & \\
\hline Female & 52 & 43.33 & & \\
\hline \multicolumn{5}{|l|}{ Age } \\
\hline $20-39$ & 10 & 8.33 & & \\
\hline $40-59$ & 75 & 62.50 & 52 & 13.6 \\
\hline $60-79$ & 35 & 29.17 & & \\
\hline \multicolumn{5}{|l|}{ Household size } \\
\hline $1-5$ & 97 & 80.83 & & \\
\hline $6-10$ & 21 & 17.5 & 5 & 0.8 \\
\hline $11-15$ & 02 & 1.67 & & \\
\hline \multicolumn{5}{|l|}{ Marital status } \\
\hline Married & 19 & 15.83 & & \\
\hline Partner & 36 & 30.00 & & \\
\hline Divorced & 33 & 27.50 & & 0.7 \\
\hline Living apart not divorced & 15 & 12.50 & & \\
\hline Widow or Widower & 11 & 9.17 & & \\
\hline Single & 6 & 5.00 & & \\
\hline \multicolumn{5}{|l|}{ Education level } \\
\hline No education & 37 & 30.83 & & \\
\hline Primary education & 40 & 33.33 & 7 & 2.2 \\
\hline Secondary education & 39 & 32.50 & & \\
\hline Tertiary education & 4 & 3.33 & & \\
\hline \multicolumn{5}{|l|}{ Source of Income } \\
\hline Farming & 45 & 37.50 & & \\
\hline Family and friends & 15 & 12.50 & & \\
\hline Grants & 55 & 45.83 & & \\
\hline Cooperatives & 0 & 0.00 & & \\
\hline Bank loan & 3 & 2.50 & & \\
\hline Others & 2 & 1.67 & & \\
\hline \multicolumn{5}{|l|}{ Income Per Annum (Rand) } \\
\hline $1-20000$ & 87 & 72.50 & R18000/ \$1325.55 & \\
\hline $20001-40000$ & 21 & 17.50 & & \\
\hline $40001-60000$ & 8 & 6.67 & & \\
\hline $60001-80000$ & 2 & 1.67 & & \\
\hline 80001-100000 & 1 & 0.83 & & \\
\hline
\end{tabular}




\begin{tabular}{lcc} 
& $\begin{array}{c}\text { Journal of Economics and Behavioral Studies (ISSN: 2220-6140) } \\
\text { Vol. 10, No. 1, pp. 22-32, February 2018 }\end{array}$ \\
\hline \hline 100001 and above & 1 & 0.83 \\
Asset Possession & & \\
Yes & 41 & 34.17 \\
No & 48 & 40.00 \\
Not Sure & 31 & 25.83 \\
Food security status & & \\
Food secure & 49 & 40.83 \\
Food insecure & 71 & 59.17 \\
\hline
\end{tabular}

Note: Exchange rate as at Dec., 2017: \$1US was equivalent to R13.58

Source: Computed from Field Survey

Respondents Perception and Knowledge of Climate change in Limpopo Province: Table 2 shows that all the 15 climate change perception and knowledge indicators were rated yes or no by the respondents with majority of the respondents indicating yes for all the perception questions while (51.67\%) of the respondents claimed not to be knowledgeable about climate change. The implication is that although majority of these respondents lack formal knowledge of climate change, yet they can perceive and observe its incidence on their livelihood and agricultural activities. This is in line with the conclusion of Maponya and Mpandeli (2013), in their study that barriers like lack of education and skills and information, lack of government support are core problems of rural communities of Limpopo Province which should be addressed.

Table 2: Perception and knowledge of Climate Change Profile of the Respondents

\begin{tabular}{|c|c|c|c|c|c|c|}
\hline $\mathbf{N}$ & Climate change Knowledge and Perception Indicators & YES & & NO & & \\
\hline & & Freq & $\%$ & Freq & $\%$ & SD \\
\hline 1 & Aware of climate change & 88 & 73.33 & 32 & 26.67 & 0.78 \\
\hline 2 & Knowledgeable on climate change & 58 & 48.33 & 62 & 51.67 & 0.66 \\
\hline 3 & Perception of erratic rainfall pattern & 101 & 84.17 & 19 & 15.83 & 0.79 \\
\hline 4 & Perception of presence of draught & 116 & 96.67 & 04 & 3.33 & 0.96 \\
\hline 5 & Perception of reduction in soil moisture & 91 & 75.83 & 29 & 27.17 & 0.71 \\
\hline 6 & Perception of reduction in crop yield \& animal harvest & 112 & 93.33 & 08 & 6.67 & 0.58 \\
\hline 7 & Perception of rise in temperature & 115 & 95.83 & 05 & 4.17 & 1.02 \\
\hline 8 & Perception or observation of flooding of farmland & 102 & 85.00 & 18 & 15.00 & 0.71 \\
\hline 9 & Perception or observation of heavy wind/storm & 89 & 74.17 & 31 & 25.83 & 0.55 \\
\hline 10 & Perception or observation of soil erosion & 76 & 63.33 & 44 & 36.67 & 0.59 \\
\hline 11 & Perception of high pest \& disease infestation & 63 & 52.50 & 57 & 47.50 & 0.88 \\
\hline 12 & Crop failure and animal mortality & 117 & 97.50 & 3 & 2.50 & 0.82 \\
\hline 13 & Incurred more cost on investment & 119 & 99.17 & 1 & 0.83 & 0.81 \\
\hline 14 & Reduction of plant and livestock's quality and quantity & 77 & 64.17 & 43 & 35.83 & 0.65 \\
\hline 15 & Delay in planting and livestock production & 111 & 92.50 & 9 & 7.50 & 0.74 \\
\hline
\end{tabular}

Source: Computed from Field Survey

Modelling the Correlates of the Determinants of Climate Change in the Limpopo Province of South Africa: This section estimated the determinants of the farming households' perception of climate change in Limpopo South Africa using Tobit regression model. High level of tolerance computed for the variables indicates that there was absence of serious multicollinearity in the analysis. In order to avoid inconsistency and biasness from the estimated parameters, the study subjected the variables to multicollinearity test using Collin command in STATA 11. Test for multicollinearity among the variables was carried out with variance inflation factor (VIF) see Table 3. Since some of the variables that were included to capture the respondent demographic and environmental characteristics showed statistical significance, the null hypothesis is for this specific objective is therefore rejected. Following the procedure earlier described above, Principal Component Analysis was employed to construct the climate change index which was the dependent variable in the Tobit regression. Table 4 shows that eight out of the seventeen fitted independent variables in the analysis were significant. The variables that significantly affect the households' perception of climate change were type of crop grown $(\mathrm{p}<0.01)$, reduction in soil moisture $(\mathrm{p}<0.01)$, knowledge of climate change $(\mathrm{p}<0.10)$, climate change adaptation $(\mathrm{p}<0.01)$, agricultural activities $(\mathrm{p}<0.05)$, bush burning practice $(\mathrm{p}<0.01)$, tree 
cutting $(\mathrm{p}<0.01)$ and farm activities leading to soil erosion $(\mathrm{p}<0.01)$. While other variables were statistically insignificant $(\mathrm{p}>0.10)$.

Table 4 shows that the parameter of the type of crop grown by the farmers was negative $(-0.55700)$ and significant $(\mathrm{p}<0.01)$. This indicates a negative relationship between the type of crop grown by the farmers and their perception of climate change in the study area. This could largely be due to the low educational level of this respondent and or due to inadequate knowledge of climate change in the study area as their perception of climate change supposed to positively affect the type of crop to be grown at all times so as to avoid the negative impact of climate change in the study area. Likewise, the parameter of the farming households' perception of reduction in soil moisture captured in its dummy form was observed to be statistically negative $(-0.95933)$ and significant $(\mathrm{p}<0.01)$. On the other hand, the coefficient of respondents' knowledge of climate change was positive $(0.01909)$ and significant $(p<0.10)$ in the model. It implies that if the households' heads knowledge of climate change increase with increase in their perception of climate change. This is realistic because knowledge arouses the perception of an event. Adequate knowledge of climate change will help the farmers to know the rightful perception of climate change and how to possibly avoid its consequences in the study area. Climate change adaptation parameter was realized to be positive (0.24197) and significant at $(\mathrm{p}<0.01)$, indicating a positive and direct relationship between the respondents' adaptation of method of preventing climate change impact and climate change perception in the study area. The coefficient of agricultural activities which could contribute to climate change threat was positive $(0.16667)$ and significant at $(\mathrm{p}<0.05)$ in the study. This implies that adaptation of climate change strategies contributes positively to climate change in the study. The dummy parameter of bush burning practice by the respondents also gave a positive $(0.85730)$ and significant $(\mathrm{p}<0.01)$, in the study. This stand to explain that bush burning contributes to climate change in the study, this is expected as bush burning leads to emission of gases that contributes to climate change. Tree cutting coefficient was further found to be positive (1.87526) statistically significant $(\mathrm{p}<0.01)$. This by implication indicates that tree cutting contributes to climate change as there is positive relationship between the two as founded in this study. Finally, farm activities leading to soil erosion was positive (3.76161) and significant to climate change at $(\mathrm{p}<0.01)$. This means there is a positive link between the soil erosion and climate change in the study area.

Table 3: Multicollinearity Test of Variables

\begin{tabular}{llll}
\hline Variables & VIF & Tolerance & Eigenvalue \\
\hline Household Size & 1.80 & 0.5568 & 13.0490 \\
Climate change Adaptation method & 1.68 & 0.5938 & 1.0940 \\
Household Heads' Age & 1.48 & 0.6737 & 1.0666 \\
Educational Status of the Head & 1.50 & 0.6669 & 0.8759 \\
Credit Accessibility & 2.11 & 0.4735 & 0.4997 \\
Food Security status & 2.37 & 0.4220 & 0.3388 \\
Reduction in Soil Moisture & 6.08 & 0.1645 & 0.2806 \\
Asset Ownership & 2.02 & 0.4950 & 0.2130 \\
Knowledge of Climate change & 1.28 & 0.7788 & 0.1836 \\
Household Income & 4.89 & 0.2043 & 0.1473 \\
Food Expenditure & 4.03 & 0.2483 & 0.0882 \\
Type of Crop Grown & 6.10 & 0.1638 & 0.0562 \\
Agricultural activities & 1.59 & 0.6281 & 0.0330 \\
Release of methane or Co from Farm Activities & 1.70 & 0.5899 & 0.0297 \\
Bush Burning practice & 1.87 & 0.5341 & 0.0206 \\
Tree cutting & 1.47 & 0.6784 & 0.0117 \\
Farm activities leading to soil erosion & 1.64 & 0.6110 & 0.0110 \\
\hline Source: Aucts Comp
\end{tabular}

Source: Authors Computation from the Computer Printout of Multicollinearity Test 
Table 4: Tobit Results of the Correlates of the Determinants of Climate Change

\begin{tabular}{llllll}
\hline Variables & Coefficient & Std. Error & $\mathbf{t}$ & $\mathbf{P}>/ \mathbf{t} /$ & Tolerance \\
\hline Household Size & -0.01078 & 0.03369 & -0.32 & 0.749 & 0.5568 \\
Type of Crop Grown & -0.55700 & 0.16308 & -3.42 & 0.001 & 0.5938 \\
Household Heads' Age & 0.11447 & 0.09087 & 1.26 & 0.211 & 0.6737 \\
Educational Status of the Head & -0.05803 & 0.03854 & -1.51 & 0.135 & 0.6669 \\
Credit accessibility & -0.60255 & 0.46806 & -1.29 & 0.201 & 0.4735 \\
Food Security status & 0.07928 & 0.44559 & 0.18 & 0.859 & 0.4220 \\
Reduction in Soil Moisture & -0.95933 & 0.29288 & -3.28 & 0.001 & 0.1645 \\
Asset Ownership & -0.03863 & 0.03179 & -1.22 & 0.227 & 0.4950 \\
Knowledge of Climate change & 0.01909 & 0.01075 & 1.77 & 0.079 & 0.7788 \\
Household Income & 0.04131 & 0.12773 & 0.32 & 0.747 & 0.2043 \\
Food Expenditure & -0.03486 & 0.08329 & -0.42 & 0.676 & 0.2483 \\
Climate change Adaptation & 0.24197 & 0.05442 & 4.45 & 0.000 & 0.1638 \\
Agricultural activities & 0.16667 & 0.07199 & 2.32 & 0.023 & 0.6281 \\
Release of methane or Co from Farm & -0.03016 & 0.08971 & -0.34 & 0.737 & 0.5899 \\
Bush burning practice & 0.85730 & 0.16145 & 5.31 & 0.000 & 0.5341 \\
Tree cutting & 1.87526 & 0.32353 & 5.80 & 0.000 & 0.6784 \\
Farm activities leading to soil erosion & 3.76161 & 0.29843 & 12.60 & 0.000 & 0.6110 \\
Constant & 0.89385 & 1.46460 & 0.61 & 0.543 & \\
\hline Observation Number & 120 & & & & \\
LR chi & 126.34 & & & & \\
Prob>ch & 0.0000 & & & & \\
Log likelihood & -120.35058 & & & &
\end{tabular}

Source: Authors Computation from Computer Printout of Tobit Regression Analysis

Probit Regression Analysis of the Factors influencing Households' Food Security in Limpopo Province of South Africa: Table 6shows the results of the Probit regression which determined the factors influencing farming household's food security in Limpopo Province of South Africa. Test for multicollinearity among the variables was carried out with variance inflation factor (VIF) and the mean VIF of the variables was good (See Table 5). The marginal parameters were also used for interpretation of the results. In order to avoid inconsistency and biasness from the estimated parameters, the study subjected the variables to multicollinearity test using Collin command in STATA. The result shows that the model produced good fits for the data as revealed by statistical significance of the Likelihood Ratio Chi-Square $(p<0.01)$. Also, high level of tolerance computed for the variables indicates that there was absence of serious multicollinearity in the analysis. In the study, eight out of the fourteen variables analysed were found to be significantly influencing farming households' food security status in the study area. These variables include gender of the household's head, employment status, age of the household's head, experience of shock, climate change, high food price, educational status and food expenses. The parameter of household heads' gender was statistically significant $(p<0.10)$ with a positive coefficient $(0.97787)$ to respondents' food security status $(0$ if food secure and 1 otherwise) in this model. This indicates thatgender of the household's head positively influenced the probability of households' food security in the study area. This further implies that being a male headed household's category had a significantly higher probability of influencing their food security status in the study area. This could be due to the fact that male are more active head than female counterparts.

The coefficient of employment status of respondents was also found to be positive (0.39819) and significant $(\mathrm{p}<0.01)$ to their food security status. This indicates that the employed respondents in the study area have a higher probability of being food secured when compared with their unemployed counterpart. This is understandable in the sense that, respondents with employed status will have income and so could afford to shoulder the feeding cost of the entire household. This is contrary to the counterparts who might not be able to afford the basic necessity of the households. In addition, age of the households' head was negatively (0.63566) and significant $(\mathrm{p}<0.01)$. This indicates that decrease in age of the farming household head increases the probability of farming households' food security status. This might be due to the fact that younger household head has more strength and agility to make money in other to take care of his household member thereby enhancing their food security unlike their older counterparts in the study area. Experience 
of shocks (captured in its dummy form) parameter was negative $(-0.22214)$ and statistically significant $(\mathrm{p}<0.05)$. This means that decrease in household heads' shock experiences increases the household's probability of being food secured in the study area. This is not in line with the a priori expectation of the study. Furthermore, the coefficient of respondents' climate change (captured as generated PCA climate change index) was negative $(-1.64456)$ and significant $(\mathrm{p}<0.10)$. This means that decrease in the climate change incidence increases the probability of the farming households' food security status in the study area. This is expected as decrease in climate change impact leads to increase in food security status and better livelihood of the farming households in the study area.

The study further observed that the parameter of high food prices captured in its dummy form was negative $(-1.61965)$ and significant at $(\mathrm{p}<0.05)$ to respondents' food security status in the study area. This by implication means that decrease in prevailing food prices in the study area leads to increase in the probability of respondent food security in the study. This is in consonance with apriori knowledge as there is inverse relationship between high food prices and food security as increase in food prices could lead to food insecurity vice versa in the study. Educational status of the respondent was positively (2.11125) significant $(\mathrm{p}<0.10)$. This indicates that increase in the educational status of the farming households' head increases the probability of increasing their food security status in the study area. This is not in line with the apriori expectation of the study as education is a key indicator to alleviation of poverty and hunger. Finally, the coefficient of respondents cost of food expenditure was negative $(-1.06089)$ and significant at $(p>0.05)$. This indicates a negative relationship between the farming households' food expenditure and their food security status. By implication, this stands to say, the respondent's cost of nutrition has a lower probability of influencing their food security status. This could be as a result of the fact that these respondents are largely small-scale farmers who feed on their self-farm outputs or because they have other coping strategies to shortage in food in their households.

Table 5: Multicollinearity Test of Variables

\begin{tabular}{llll}
\hline Variables & VIF & Tolerance & Eigenvalue \\
\hline Household size & 1.72 & 0.5819 & 10.2807 \\
Gender of the Household head & 1.86 & 0.5374 & 1.1689 \\
Employment status & 1.59 & 0.6306 & 1.0623 \\
Age of the Household's head & 1.42 & 0.7018 & 1.0481 \\
Experience of Shock & 1.67 & 0.5989 & 1.0132 \\
Theft Incidence & 4.40 & 0.2982 & 0.7053 \\
Climate change & 1.57 & 0.6376 & 0.3379 \\
High food price & 1.63 & 0.6134 & 0.2735 \\
Educational status & 2.85 & 0.3515 & 0.1613 \\
Possession of Asset & 1.67 & 0.5980 & 0.1544 \\
House materials & 1.26 & 0.7935 & 0.0649 \\
Farm size & 1.21 & 0.8294 & 0.0551 \\
Farming experience & 1.12 & 0.8964 & 0.0380 \\
food expenses & 1.50 & 0.6682 & 0.0274 \\
\hline Source Authors Computation
\end{tabular}

Source: Authors Computation from the Computer Printout of Multicollinearity Test 
Journal of Economics and Behavioral Studies (ISSN: 2220-6140)

Vol. 10, No. 1, pp. 22-32, February 2018

Table 6 : Probit Analysis of the Factors influencing Households' Food Security

\begin{tabular}{lllllll}
\hline Variables & Coefficient & Std. Error & $\mathbf{Z}$ & $\mathbf{P}>\mid \mathbf{z}$ & $\mathbf{M . E}$ & $\begin{array}{l}\text { Toleranc } \\
\mathbf{e}\end{array}$ \\
\hline Household size & 0.16960 & 0.12934 & 1.31 & 0.190 & .04977 & 0.5819 \\
Gender of the House head & 0.97787 & 0.52264 & 1.87 & 0.061 & 0.2869 & 0.5374 \\
Employment status & 0.39819 & 0.14844 & 2.68 & 0.007 & 0.1168 & 0.6306 \\
Age of the Household's head & -0.63566 & 0.18906. & -3.36 & 0.001 & -0.1865 & 0.7018 \\
Experience of Shock & -0.22214 & 0.11021 & -2.02 & 0.044 & -0.0651 & 0.2982 \\
Theft Incidence & 1.6556 & 1.13406 & 1.46 & 0.144 & 0.2285 & 0.1987 \\
Climate change & -1.64456 & 0.86143 & -1.91 & 0.056 & -0.2479 & 0.6376 \\
High food price & -1.61965 & 0.79462 & 2.04 & 0.042 & -0.4229 & 0.6134 \\
Educational status & 2.11125 & 1.16719 & 1.81 & 0.070 & 0.2462 & 0.3515 \\
Possession of Asset & -1.6051 & 0.98245 & -1.63 & 0.102 & -0.5759 & 0.5980 \\
House materials & 0.23490 & 0.14275 & 1.65 & 0.100 & 0.0689 & 0.4594 \\
Farm size & 0.13405 & 0.12893 & 1.04 & 0.298 & 0.0393 & 0.7935 \\
Farming experience & -0.57270 & 0.56644 & -1.01 & 0.312 & -0.1681 & 0.8294 \\
food expenses & -1.06089 & 0.48671 & -2.18 & 0.029 & -0.3113 & 0.8964 \\
Constant & 0.67633 & 2.63336 & 0.26 & 0.797 & & 0.6682 \\
\hline Observation Number & 120 & & & & & \\
LR chi ${ }^{2}(14)$ & 83.09 & & & & & \\
Prob> chi ${ }^{2}$ & 0.0000 & & & & & \\
Pseudo R & 0.5347 & & & & & \\
Log likelihood & -36.147071 & & & & &
\end{tabular}

Source: Authors Computation from Computer Printout of Probit Regression Analysis

\section{Discussion}

This paper examined the climate change and food security dynamics in the rural Limpopo Province of South Africa. Determinants and factors influencing rural households' food security were analyzed by the study. The descriptive results indicate Average year of formal education by the households' head was 7 years, which implies a low educational attainments of the household heads in the rural communities. Low attainment of formal education could also influence knowledge and perception of climate change and food security in the study area. Several studies have emphasized the importance of education on knowledge, perception and food security (Parry et al., 1999; Di Falco et al.,2011; Godfray et al., 2010). The result also indicated that the knowledge of climate change is still low in the study. This is obviously a reflection of low educational attainments among the rural household heads as previously reported by Sharma (Knox et al., 2012). The findings are also bringing to fore the essence of moderate household size. In some related studies (Nord 2010; Kennedy and Peters, 1992) interventions to enhance knowledge of family size should be enhanced. An average annual income of R18000 (\$1325.55) was recorded in the study which was supported by the respondents' response on their possession of asset which $40 \%$ of them claimed not to have. This indicate a high level of poverty in the study area while $59.17 \%$ of the respondent were found to be food insecure. This is in line with the report by Rule et al., (2005) which confirmed that most of the households experienced lack of food or money. In conclusion, thee study revealed that majority of the respondents lack knowledge of climate change while the correlates of the determinants of climate change in the study area were knowledge of climate change, climate change adaptation, agricultural activities, bush burning practice, practice of tree cutting, farm activities leading to soil erosion, crop grown and reduction in soil moisture. The findings also showed that factors influencing households' food security in Limpopo Province of South Africa were gender of the household's head, employment status, age of the household's head, experience to react on shocks, climate change adaptation, high food price, educational status of the household head? And food expenses. It was recommended that:

- Training of extension agents should be carried out on regular bases to equip the rural farmers with the knowledge of climate change and its effect on household's food security so that they can easily 
help to disseminate to these rural households, in order to improve the rural farmers' agricultural production and wellbeing.

- The Premier of Limpopo Province and indeed South Africa government should improve on the socioeconomic characteristics of the rural communities by empowering them through some unskilled trainings which can be a backup off-farm activity so as to enable them to economically combat the impact of climate change to improve on food security of the nation, South Africa.

- Extension visit is recommended for farmers in Limpopo province to raise the level of perception and knowledge of farmers on the impact of climate change so that they will desist from agricultural activities such as bush burning practice, tree cutting etc. in the study area.

- The government of South Africa should endeavour to implement a more rural focused food securityclimate change policy in order to help relieve the intensity of food insecurity situations among these disadvantaged rural dwellers of the province as well as to entrench a policy of long term development of agriculture.

Acknowledgements: The support of my family at all times is deeply appreciated. I also appreciate the North West University for providing the enabling environment and finance for the success of this research.

\section{References}

Adeniyi, A. B., Daud, A. S., Amao, O. \& Omotayo, A. O. (2016). Determinants of Rural Women's Livelihood in Ibarapa North Local Government Area of Oyo State, Nigeria. Journal of Human Ecology, 56(1,2), 8490. Retrieved January 17, 2018.

DAFF (Department of Agriculture, Forestry and Fisheries). (2012), Strategic Plan: 2012/13-2016/17. Pretoria: DAFF. ww.nda.agric.za/doaDev/topMenu/StratPlan201213-201617.pdf. Retrieved September 4, 2017.

De Cock, N., D’Haese, M., Vink, N., Van Rooyen, C. J., Staelens, L., Schönfeldt, H. C. \& D’Haese, L. (2013). Food security in rural areas of Limpopo province, South Africa. Food Security, 5(2), 269282.https://link.springer.com/article/10.1007/s12571-013-0247-y

Di Falco, S., Veronesi, M. \& Yesuf, M. (2011). Does adaptation to climate change provide food security? A micro-perspective from Ethiopia. American Journal of Agricultural Economics, 93(3), 829-846.

Godfray, H. C. J., Beddington, J. R., Crute, I. R., Haddad, L., Lawrence, D., Muir, J. F., Pretty, J., Robinson, S., Thomas, S. M. \& Toulmin, C. (2010). Food security: the challenge of feeding 9 billion people. science, 327(5967), 812-818.

Ifeoma, I. \& Agwu, A. (2014). Assessment of food security situation among farming Households in rural areas of Kano state, Nigeria. Journal of central European agriculture, 15(1).

International Found for Agricultural Development (IFAD). (2008). Climate change: A Development challenge. https://www.ifad.org/topic/resource/tags/climate_change/2082522. Retrieved September 5, 2017.

Joosten, K. \& Grey, S. (2017). Integrating climate change adaptation and mitigation into the watershed management approach in eastern Africa - Discussion paper and good practices. Addis Ababa, Fao. http://www.fao.org/3/a-i7489e.pdf. Retrieved September 4, 2017.

Karl, T. R. (2009). Global climate change impacts in the United States. Cambridge University Press. http://www.epa.gov/climaticchange/downloads/climatic- Basics.pdf. Retrieved September $5,2017$.

Kennedy, E. \& Peters, P. (1992). Household food security and child nutrition: the interaction of income and gender of household head. World development, 20(8), 1077-1085.

Knox, J., Hess, T., Daccache, A. \& Wheeler, T. (2012). Climate change impacts on crop productivity in Africa and South Asia. Environmental Research Letters, 7(3), 034032.

Lal, P., Alavalapati, J. \& Mercer, D. E. (2011). Socioeconomic impacts of climate change on rural communities in the United States. http://www.arlis.org/docs/vol1/C/724675663.pdf\#page=83

Maponya, P. \& Mpandeli, S. (2013). Perception of farmers on climate change and adaptation in Limpopo Province of South Africa. Journal of Human Ecology, 42(3), 283288.http://www.krepublishers.com/02-Journals/JHE/JHE-42-0-000-13-Web/JHE-42-3-000-13Abst-PDF/JHE-42-3-283-13-2381-Maponya-P/JHE-42-3-283-13-2381-Maponya-P-Tx[9].pmd.pdf

Manyatsi, A. M., Mhazo, N. \& Masarirambi, M. T. (2010). Climate variability and change as perceived by rural communities in Swaziland. Research Journal of Environmental and Earth Sciences, 2(3), 164-169. http://maxwellsci.com/print/rjees/v2-164-169.pdf. Retrieved September 4, 2017. 


\section{Journal of Economics and Behavioral Studies (ISSN: 2220-6140)}

Vol. 10, No. 1, pp. 22-32, February 2018

Nord, M. (2010). Household food security in the United States, 2009 (Vol. 108). DIANE publishing.

Omonona, B., Agoi, T. \& Adetokunbo, G. (2007). An analysis of food security situation among Nigerian urban households: Evidence from Lagos State, Nigeria. Journal of Central of European Agriculture, 8(3), 399406.

Omotayo, A. O., Aremu, B. R. \& Alamu, O. P. (2016). Food Utilization, Nutrition, Health and Farming Households' Income: A Critical Review of Literature.

Omotayo, A. O. (2017). Economics of farming household's food intake and health-capital in Nigeria: A twostage probit regression approach. The Journal of Developing Areas, 51, (4), 109-125 | 10.1353/jda.2017.0091.https://ideas.repec.org/a/jda/journl/vol.51year2017issue4pp109125.html. Retrieved September 5, 2017.

Parry, M., Rosenzweig, C., Iglesias, A., Fischer, G. \& Livermore, M. (1999). Climate change and world food security: a new assessment. Global environmental change, 9, S51-S67.

Perret, S., Anseeuw, W. \& Mathebula, N. (2005). Poverty and livelihoods in rural South Africa. Investigating diversity and dynamics of livelihoods. Case studies in Limpopo. Unpublished Project report num.05/01, Kellogg's Foundation / University of Pretoria, 65p.

Rule, S., Aird, R., Drimie, S., Faber, M., Germishuyse, T., Jordaan, A. \& Schawbe, C. (2005). Report on survey in Sekhukhune to pilot the development of a food insecurity and vulnerability modelling system (FIVIMS) for South Africa. Unpublished Final Report. Department of Agriculture. Pretoria.

Statistics South Africa, (2011). General Household Survey, 2009. Pretoria: Statistics South Africa. Pp 6-10. http://www.statssa.gov.za/publications/P0318/P03182009.pdf.

Team, C. W., Pachauri, R. K. \& Reisinger, A. (2007). Contribution of working groups I, II and III to the fourth assessment report of the intergovernmental panel on climate change. IPCC, Geneva, Switzerland. https://www.ipcc.ch/pdf/assessment-report/ar4/syr/ar4_syr_full_report.pdf. Retrieved September 5, 2017.

Tobin, J. (1958). Estimation of relationships for limited dependent variables. Econometrica: journal of the Econometric Society, 2, 24-36.http://www.jstor.org/stable/1907382?seq=1\#page_scan_tab_contents 